\title{
INISIASI PENGUATAN PERILAKU PENCEGAHAN COVID-19 PADA PANTI ASUHAN BETLEHEM
}

\author{
Henrita Ernestia ${ }^{1}$, \\ Manasye Sabri Agustaputra ${ }^{2}$, Nurul Khadijah ${ }^{2}$, Ciciliananda Bela Novidwiyani², \\ Florentina Dewi Pramesuari², Megi Juliantini ${ }^{2}$
}

\author{
${ }^{1}$ Program Field Lab, Fakultas Kedokteran, Universitas Katolik Soegijapranata, Semarang, Indonesia \\ ${ }^{2}$ Fakultas Kedokteran Universitas Katolik Soegijapranata Semarang, Indonesia \\ Korespondensi Penulis: \\ Nama $\quad$ : dr. Henrita Ernestia, M.Biomed, AAM \\ Alamat : Jl. Pawiyatan Luhur IV No. 1 Bendan Duwur - Semarang 50234 - Indonesia \\ Nomor Telepon : 8441555 (hunting) \\ Email : : henrita@unika.ac.id
}

\begin{abstract}
Abstrak
Latar Belakang : Pandemi COVID-19 mengubah cara hidup dan membatasi aktivitas keseharian setiap orang termasuk penghuni panti Asuhan Betlehem di Kota Semarang. Kondisi pandemi yang berkepanjangan berdampak pada praktik personal hygiene dan penerapan protokol COVID-19. Masalah ini terjadi karena kurangnya edukasi kesehatan dan keterbatasan ketersediaan sarana prasarana yang dibutuhkan.

Tujuan Penelitian : Penelitian ini bertujuan mengidentifikasi masalah kesehatan yang ada di lingkungan panti dan mengukur preaseptabilitas kebutuhan dan kesiapan komunitas untuk perubahan perilaku khususnya mengenai perubahan perilaku personal hygiene dan perilaku sesuai protokol kesehatan COVID-19.

Metode : Jenis penelitian ini adalah preliminary study (studi pendahuluan). Teknik sampling menggunakan purposive sampling dengan kriteria inklusi adalah pengurus panti, penghuni panti yang sudah tinggal di panti lebih dari 1 tahun, dapat berkomunikasi dengan baik, dan bersedia terlibat dalam proses intervensi yang dilakukan. Sedangkan kriteria ekslusi adalah anak panti yang tidak tinggal di asrama, dan tidak dapat berkomunikasi dengan baik. Metode pengumpulan data menggunakan wawancara semi berstruktur dan observasi langsung, Analisis data dalam penelitian ini adalah analisis univariat dimana peneliti hanya menyajikan data secara deskripif.

Kesimpulan : Hasil penelitian ini menunjukkan bahwa intervensi yang dilakukan dapat memberikan potensi perubahan perilaku menjadi lebih baik. Walaupun penelitian ini merupakan penelitian pendahuluan (preliminary study), tetapi data yang diperoleh dapat menjadi masukkan dan mapping bahwa intervensi untuk perubahan perilaku di panti asuhan bisa ditingkatkan ke level penelitan yang lebih besar.
\end{abstract}

Kata kunci: personal hygiene, protokol kesehatan COVID-19, perubahan perilaku, panti asuhan.

\section{Pendahuluan}

Pandemi COVID-19 mengubah cara hidup dan membatasi aktivitas keseharian setiap orang. Kondisi ini membuat orang merasa cemas dan stres dalam melakukan aktivitas di luar rumah. Kondisi ini juga di alami oleh penghuni Panti Asuhan Betlehem Kota Semarang. Panti Asuhan Betlehem, merupakan lembaga sosial yang bertanggung jawab memberikan pelayanan kesejahteraan sosial pada anak terlantar, memiliki keterbatasan dalam bidang kesehatan, baik masalah kesehatan yang berkaitan dengan kebersihan diri termasuk menyesuaikan dengan protokol kesehatan di masa pandemi. Masalah kesehatan ini terjadi karena kurangnya edukasi kesehatan yang diterima oleh penghuni panti serta keterbatasan ketersediaan sarana prasarana yang dibutuhkan. 
Dimasa pandemi behavioral changes (perubahan perilaku) harus diadaptasi bahkan cenderung harus dipaksakan. Untuk memahami masalah di Panti Asuhan Betlehem, dilakukan assessment awal untuk menilai perilaku sebelumnya, kemudian dilakukan intervensi sehingga dapat dirubah atau dimodifikasi untuk menyesuaikan dengan kondisi pandemi. Perubahan perilaku tersebut dilakukan bukan hanya untuk jangka pendek tetapi harus dilakukan sebagai respon adaptif jangka panjang karena adanya pandemi COVID-19. ${ }^{(1)}$

Port the entre virus COVID-19 adalah melalui hidung, mulut dan mata, dengan demikian tindakan pencegahan penularan yang perlu dilakukan adalah untuk mencegah masuknya virus melalui port the entre tersebut. Personal hygiene dan penerapan protokol kesehatan yang benar akan mengurangi tingkat keterpaparan penularan COVID-19 di lingkungan yang tinggal berkelompok seperti panti asuhan. Untuk mencegah risiko tertular virus COVID-19 pemerintah menyarankan untuk melakukan prokes $3 \mathrm{M}$ yang meliputi; memakai masker, menjaga jarak dan mencuci tangan. Untuk mengurangi penyebaran virus COVID-19 ditambahkan menjadi 5 M sebagai dukungan dari prokes $3 \mathrm{M}$ tersebut dengan; menjauhi kerumunan dan mengurangi mobilitas. ${ }^{(2)}$

Untuk melindungi diri dari risiko penularan COVID-19 tidak saja seseorang harus merubah perilaku, tetapi juga harus memiliki pengetahuan yang cukup sehingga dapat merubah menjadi perilaku dengan benar. Prokes pertama yaitu menggunakan masker, Satgas COVID-19 BNPB memberikan panduan cara menggunakan masker yang benar sebagai berikut; 1. Sebelum memasang masker, cuci tangan pakai sabun dan air mengalir (minimal 20 detik) atau bila tidak tersedia, gunakan cairan pembersih tangan (minimal alkohol 60\%); 2. Pasang masker untuk menutupi mulut dan hidung dan pastikan tidak ada sela antara wajah dan masker; 3 . Hindari menyentuh masker saat digunakan; bila tersentuh, cuci tangan pakai sabun dan air mengalir minimal 20 detik atau bila tidak ada, cairan pembersih tangan (minimal alkohol 60\%); 3. Ganti masker yang basah atau lembab dengan masker baru. Masker medis hanya boleh digunakan satu kali saja. Masker kain dapat digunakan berulang kali; 4. Untuk membuka masker: lepaskan dari belakang. Jangan sentuh bagian depan masker; Untuk masker 1x pakai, buang segera di tempat sampah tertutup atau kantong plastik. Untuk masker kain, segera cuci dengan deterjen. Untuk memasang masker baru, ikuti poin pertama. ${ }^{(3)}$

Menjaga jarak minimal 1meter dengan orang lain untuk menghindari terkena droplet virus COVID-19 dari orang yang bicara, batuk, bersin atau bernyanyi karena droplet virus dapat terlontar hampir sejauh 1 meter adalah prokes yang kedua. Prokes ketiga adalah mencuci tangan sesuai protokol kesehatan dan atau menggunakan hand sanitizer setelah memegang benda benda karena droplet virus COVID-19 dari orang yang terinfeksi akan jatuh ke benda-benda dan menempel sehingga menciptakan permukaan benda yang terkontaminasi. Orang yang memegang benda yang terkontaminasi tersebut 
dapat dapat terinfeksi juga apabila menyentuh mata, hidung, atau mulut yang merupakan port the entre sebelum mencuci tangan. ${ }^{(4)}$

Dalam upaya mencegah penyebaran COVID-19 pemerintah meminta masyarakat untuk menjauhi kerumunan dan mengurangi mobilitas yang merupakan prokes ke 4 dan ke 5. Dalam upaya menekan laju penyebaran COVID-19 pemerintah juga memberlakukan aturan Pembatasan Sosial Berskala Besar (PSBB) dan atau Pemberlakuan Pembatasan Kegiatan Masyarakat (PPKM) yang diberlakukan secara berkala dimulai sejak April 2020 sampai dengan sekarang, yang diatur dalam Peraturan Pemerintah Nomor 21 Tahun 2020.(5) (6)

Anak anak yang tinggal di panti asuhan termasuk kelompok yang rentan terhadap penularan berbagai penyakit termasuk COVID-19. Kualitas dan perilaku kesehatan mereka sepenuhnya bergantung pada pengurus dan atau pengelola panti sehingga jauh lebih rentan dari anak yang tinggal bersama orang tua.

Pada masa pandemi seharusnya anak anak panti asuhan mendapat perhatian khusus mengenai edukasi cara pencegahan dan penularan COVID-19, dan mendapatkan bimbingan untuk meningkatkan perilaku hidup bersih sehat (personal hygiene) dan menerapkan protokol kesehatan 5M menjadi kebiasaan sehari hari, serta mendapatkan kebutuhan ekstra ketersediaan masker, hand sanitizer, sabun cuci tangan juga jaminan perawatan kesehatan bila mereka tertular COVID-19. Personal hygiene berasal dari bahasa Yunani yang berarti personal yang artinya perorangan dan hygiene yang berarti sehat. Jadi personal hygiene adalah suatu tindakan untuk memelihara kebersihan dan kesehatan seseorang untuk kesejahteraan fisik dan psikis. Personal hygiene atau kesehatan diri adalah upaya seseorang dalam memelihara kebersihan dan kesehatan untuk memperoleh kesehatan fisik dan psikologis. ${ }^{(7)}$

Penelitian ini merupakan bagian dari inisiasi awal pengembangan intervensi perubahan dan penguatan perilaku dimana secara spesifik bertujuan mengidentifikasi masalah kesehatan yang ada di lingkungan panti asuhan Betlehem Semarang dan mengukur preaseptabilitas kebutuhan dan kesiapan komunitas untuk perubahan perilaku khususnya mengenai perubahan perilaku personal hygiene dan perilaku sesuai protokol kesehatan COVID-19.

\section{Metode}

Jenis penelitian ini adalah preliminary study, yaitu studi pendahuluan yang sering dilakukan untuk menyempurnakan intervensi dan mengevaluasi akseptabilitas, kelayakan, biaya, dan penyerapannya. ${ }^{(8)}$ Teknik sampling menggunakan purposive sampling dengan kriteria inklusi adalah pengurus panti, penghuni panti yang sudah tinggal di panti lebih dari 1 tahun dan dapat berkomunikasi 
dengan baik, bersedia terlibat dalam proses intervensi yang dilakukan. Sedangkan kriteria ekslusi adalah anak panti yang tidak tinggal di asrama, dan yang tidak dapat berkomunikasi dengan baik. Metode pengumpulan data menggunakan wawancara semi berstruktur, dengan menyiapkan pertanyaan terlebih dahulu. Pertanyaan awal disusun berdasarkan gagasan-gagasan mengenai permasalahan yang sering dialami oleh panti asuhan.

Adapun instrumen yang digunakan mencakup pertanyaan wawancara dibagi dalam 4 bagian; 1 . Profil anak-anak panti asuhan berupa jumlah penghuni panti, daftar pendidikan, usia, agama, asal-usul, dan apakah masih memiliki orang tua ataupun tidak; 2. Kesehatan berupa penyakit yang sering menjangkiti anak-anak panti, pengobatan yang didapat saat terjadi penyakit, fasilitas berobat, imunisasi, asupan nutrisi dan check-up kesehatan; 3. Sumber air berupa asal air yang digunakan, aliran air lancar atau tidak, pembuangan limbah air, dan ketersediaan air untuk memasak; 4. Personal hygiene berupa sarana dan fasilitas kebersihan diri untuk masing-masing anak panti, alat makan pribadi, cuci tangan, penyediaan kebutuhan pribadi seperti obat, dan kebiasaan sikat gigi, keramas, mandi dalam sehari dan lain-lain.

Setelah mengidentifikasi kemungkinan permasalahan melalui wawancara, tahapan selanjutnya dilakukan observasi secara langsung. Metode observasi yang digunakan adalah observasi terbuka, dan saat observasi diketahui oleh anak-anak dan pengurus panti, sehingga terjadi interaksi secara langsung dengan responden. Pada tahap ini, dilakukan pengamatan dan dokumentasi berupa foto di ruanganruangan maupun di lingkungan panti serta melakukan pencatatan hal-hal yang diperlukan untuk melengkapi data yang diperoleh. Dokumentasi foto diambil di kamar tidur, ruang tempat berkumpul, ruang makan dan dapur serta di lingkungan panti seperti halaman dan tempat air bersih.

Analisis data dalam penelitian ini adalah analisis univariat dimana peneliti hanya menyajikan data secara deskripif tentang profil penghuni panti, kesehatan, sumber air, personal hygiene, sarana prasarana protokol pandemi, dan kebiasaan anak anak panti.

\section{Piloting Intervensi}

Program intervensi yang dilakukan berjudul "Pentingnya Menjaga Kesehatan Diri dan Mematuhi ProtokolCOVID-19 di Masa Pandemi”. Program ini meliputi beberapa aktifitas antara lain; Pertama: Penyuluhan dengan materi yang sesuai dengan pokok permasalahan penghuni panti asuhan, yaitu personal hygine dan protokol kesehatan COVID-19.

Tujuan dari pemberian materi personal hygiene adalah untuk memberipengetahuan mengenai menjaga kebersihan dan kesehatan diri yang baik dan benar terutama menekankan kebersihan area port the entre virus COVID-19 dan kebersihan tangan. Materi protokol kesehatan di masa pandemi bertujuan memberi pengetahuan mengenai pentingnya pengetahuan mengenai protokol COVID-19 dengan menekankan risiko yang bisa terjadi jika tidak mematuhi protokol kesehatan, mengenai cara 
penularan dan penyebaran virus COVID-19.

Selain penyuluhan, intervensi yang kedua adalah memberikan demonstrasi cara mencuci tangan yang benar, cara batuk yang benar dan cara memakai masker yang benar sesuai anjuran Kemenkes dengan tujuan mereka lebih mengerti bagaimana cara melakukannya dengan benar (9). Intervensi ketiga adalah dengan mengajak dan mengamati cara mereka mencuci tangan apakah sudah sesuai yang diajarkan. Intervensi keempat yaitu dengan memberikan kebutuhan yang merupakan urgensi di saat pandemi ini untuk menurunkan risiko penularan COVID-19 antar penghuni panti yaitu berupa masker, sabun cuci tangan, hand sanitizer, sikat gigi dengan penutup, mug dengan nama masing masing, tumblr dengan nama masing masing, handuk dengan nama masing masing juga seprai untuk masing masing anak, sehingga masalah pemakaian alat minum dan alat mandi secara bergantian dapat teratasi. Intervensi kelima berupa pemberian 4 poster berupa poster cara mencuci tangan yang benar, cara batuk yang benar, menjaga jarak dan jaga diri dan keluarga dari COVID-19. Sebagai reminder (pengingat) apabila mereka lupa, dan sarana belajar untuk para penghuni panti yang baru, orang tua anak panti ataupun tamu yang datang berkunjung ke panti asuhan. ${ }^{(9)}$

Dengan mempertimbangkan variasi faktor usia dan tingkat pendidikan mereka serta urgensi pandemi COVID-19 maka intervensi dilakukan semaksimal mungkin sesuai dengan kerucut pengalaman Edgar Dale tahun 1969 dan teori psikologi Bruner tahun 1966 tentang tingkatan modus belajar sehingga intervensi yang dilakukan dapat lebih maksimal. ${ }^{(8)}$

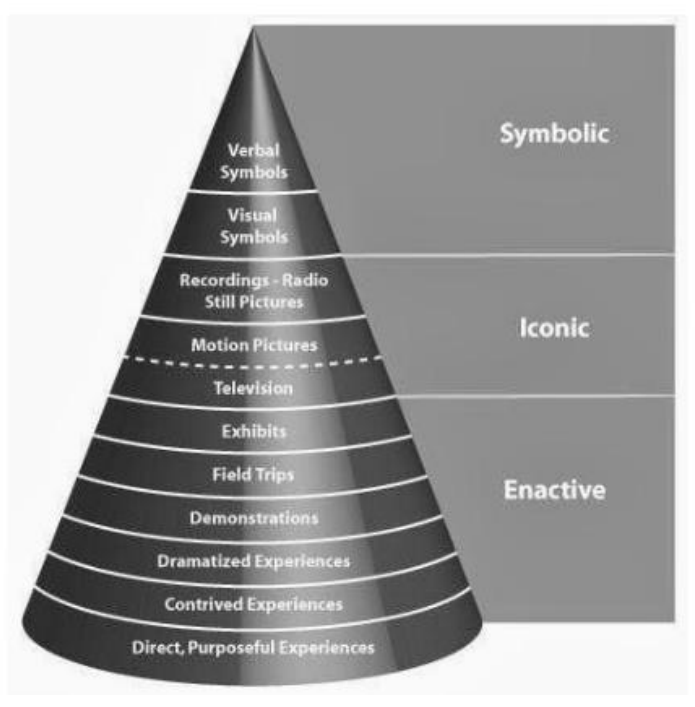

Gambar: Dale's Cones Experience 1969 (10)

Intervensi dilakukan berupa penyuluhan, materi dengan menggunakan gambar gambar yang lucu dan bergerak, mendemonstrasikan cara batuk yang benar, cara mencuci tangan yang benar, menjaga jarak dan memakai masker yang benar. Lalu praktek memakai dan melepaskan masker, cara batuk yang benar dan mencuci tangan yang benar sehingga diharapkan target dari intervensi dapat maksimal. 
Sasaran dari intervensi adalah seluruh penghuni panti. Pelaksanaan intervensi dilakukan 2 hari pada hari Sabtu dan Minggu tanggal 12-13 Juni2021, dimulai pukul 10.00 - 13.00. Satu bulan setelah intervensi dilaksanakan, dilakukan kunjungan tambahan untuk observasi langsung dan dibagikan kuestioner mengenai apakah terdapat penguatan perubahan perilaku anak panti setelah menerima edukasi, demonstrasi dan pengalaman melakukan hal yang sudah diajarkan.

\section{Hasil}

\section{Profil Panti dan Penghuni Panti Asuhan}

\section{Karakteristik Tempat Tinggal}

Panti asuhan Betlehem alamat Jl. Musi Raya No. 2 Bugangan Semarang Timur Jawa Tengah, memiliki satu bangunan utama yang terdiri dari 6 kamar tidur, 1 ruang aula, 1 ruang makan, 1 unit dapur, 1 tempat cuci pakaian dan 5 buah kamar mandi. Ukuran kamar tidur adalah 5 x 3m, Setiap kamar terdapat 3 tempat tidur yang ditempati oleh 2-3 orang anak, dalam standar layak untuk ditempati dan hanya butuh beberapa perbaikan seperti plafon yang bocor saat hujan, dilengkapi 3 lemari dengan satu kipas angin disetiap kamar. Setiap kamar posisinya strategis bisa mendapatkan sinar matahari cukup karena disetiap kamar atau ruangan terdapat ventilasi serta jendela. Pencahayaan malam hari untuk lampu menggunakan lampu bolam $L E D$ putih.

Lingkungan panti tersedia sarana air bersih, sumber air minum untuk kebutuhan anak-anak panti untuk memasak dan MCK bersumber dari air PDAM, sarana pembuangan sampah, sarana pembuangan air limbah, dan ember cuci tangan. Lingkungan tempat tingal tidak terdapat tanaman baik bunga-bunga atau pohon-pohon sebagai penaung, namun terdapat lapangan luas yang ditumbuhi rumput-rumput yang hijau, yang membuat suasana panti menjadi hijau.

\section{Kharakteristik populasi}

Tabel 1 Karakteristik Populasi Anak-Anak Panti Asuhan

\begin{tabular}{lcc}
\hline \multicolumn{1}{c}{ Karakteristik } & Jumlah & Persentase (\%) \\
\hline JenisKelamin & & \\
Laki-laki & 14 anak & $17,5 \%$ \\
Perempuan & 3 anak & \\
\hline Umur & & $17,6 \%$ \\
Dibawah 5 tahun & 3 anak & $47,05 \%$ \\
\hline $6-12$ tahun & 8 anak & $11,7 \%$ \\
\hline $13-15$ tahun & 2 anak & $23,52 \%$ \\
\hline 16 tahun ke atas & 4 anak & \\
\hline
\end{tabular}




\begin{tabular}{lcc}
\hline \multicolumn{1}{c}{ Karakteristik } & Jumlah & Persentase (\%) \\
\hline Pendidikan & & \\
Belum Sekolah-TK & 3 anak & $17,6 \%$ \\
SD & 8 anak & $47,05 \%$ \\
\hline SMP & 2 anak & $11,7 \%$ \\
\hline SMA & 3 anak & $17,6 \%$ \\
\hline Kuliah & 1 anak & $5,88 \%$ \\
\hline
\end{tabular}

Populasi dalam kegiatan ini berjumlah 17 orang anak, dengan jenis kelamin 14 orang anak laki laki penghuni panti asuhan dan 3 orang anak perempuan binaan panti tetapi tidak menghuni panti asuhan karena masih memiliki orang tua. Penghuni panti asuhan berasal dari daerah dan suku yang berbeda. Usianya terbagi dalam 4 kategori, yaitu usia dibawah 5 tahun sebanyak 3 orang (17,6\%), Usia 6-12 tahun sebanyak 8 orang (47,05\%), usia 13-15 tahun sebanyak 2 orang (11,7\%), usia 16 tahun ke atas sebanyak 4 orang $(23,52 \%)$. Dengan latar belakang pendidikan, 3 orang anak belum sekolah, yang sedang duduk di bangku SD 8 orang (47,05\%), SMP sebanyak 2 orang (11,7\%), SMA dan sederajat 3 orang (17,6\%) dan universitas 1 anak atau sebesar (5.88).

Dari data anak-anak panti asuhan, didapatkan kategori anak-anak panti berdasarkan ada tidaknya orang tua masing-masing. Anak panti yatim sebesar 31\%, yatim piatu sebesar 38\%, dan ada orang tua sebesar $31 \%$. Kelompok terbesar yaitu anak panti yatim piatu, diikuti anak panti yang yatim dan ada orang tua. Hal ini menunjukkan bahwa panti asuhan tidak hanya menampung anak panti yatim atau yatim piatu saja, tetapi juga anak panti yang masih memiliki orangtua. Anak binaan panti asuhan yang perempuan sebanyak 3 orang adalah bagian dari yang masih memiliki orang tua dan tinggal di rumah orang tua.

\section{Profil Personal Hygiene Penghuni Panti}

Kondisi personal hygiene penghuni panti sudah cukup baik, dimana penghuni panti sudah melakukan beberapa komponen menjaga kesehatan diri seperti menggosok gigi dua kali sehari namun sikat giginya tidak menggunakan penutup sementara dikumpulkan dalam satu wadah dan ini merupakan risiko penularan COVID-19, mandi dua kali sehari dengan sabun mandi, keramas cukup sering kadang kadang menggunakan shampoo. Terdapat beberapa hal yang masih kurang antara lain; jarang memotong kuku sehingga kuku terutama kuku kaki banyak yang kotor / hitam, kadang kadang masih sering menggunakan gelas secara bergantian terutama sehabis bermain atau olah raga, dan memakai handuk bergantian, dan sebagian besar anak panti tidak mencuci tangan bahkan saat akan makan siang, serta kurang tersedianya sabun cuci tangan dan tempat mencuci tangan. 


\section{Profil Perilaku Penghuni Panti Dalam Mengikuti Protokol Kesehatan}

Pemerintah meminta masyarakat untuk menerapkan protokol kesehatan 5M pada masa pandemi COVID-19 untuk mengurangi resiko penularan serta mengurangi penyebaran virus COVID-19. Mengingat bahwa penghuni panti asuhan merupakan salah satu yang rentan terhadap penularan penyakit karena tinggal berkelompok maka pengetahuan dan perubahan perilaku untuk menerapkan protokol kesehatan merupakan hal yang termasuk dalam kategori urgent harus dilakukan.

Kondisi yang ditemukan berkaitan dengan perilaku menerapkan protokol kesehatan sangat kurang, antara lain; kurangnya pengetahuan mengenai bahaya, cara penularan dan pencegahan COVID19, kurangnya mendapatkan bimbingan untuk meningkatkan perilaku hidup bersih sehat dan menerapkan protokol kesehatan 5M, kurangnya kesadaran menerapkan menggunakan masker sebagai perilaku sehari hari oleh penghuni panti.

Kurangnya ketersediaan masker sehingga hanya bila berpergian saja baru memakai masker. Tidak tersedianya sabun cuci tangan dan hanya ada 1 ember tempat cuci tangan di depan aula, dan juga rendahnya kesadaran untuk mencuci tangan, tidak terbiasa menggunakan hand sanitizer karena hanya ada 1 di ruang tamu pengurus panti. Penggunaan alat minum seperti gelas dan botol minum secara bergantian yang merupakan sarana termudah bagi penularan COVID-19.

\section{Penilaian Output Inisiasi Intervensi}

Untuk melihat atau menilai keberhasilan intervensi yang telah dilakukan, dilakukan dengan dua hal yaitu; 1. Melakukan quiz untuk menilai tingkat penerimaan pengetahuan mengenai personal hygiene, sanitasi lingkungan dan protokol kesehatan; 2. Satu bulan setelah intervensi, dibagikan kuestioner pada seluruh anak panti yang berisi pertanyaan berisi perilaku yang dilakukan setelah diberikan intervensi berupa edukasi, demonstrasi, dan simulasi mengenai personal hygiene dan melakukan protokol kesehatan 5M kepada penghuni panti, cara batuk, cara mencuci tangan 6 langkah dan cara memakai masker yang benar. Hal ini dilakukan untuk menilai berapa tingkat perubahan perilaku yang terjadi setelah intervensi diberikan.

\section{Quiz untuk menilai daya tangkap sebagai output intervensi}

Peserta program intervensi ini sudah mencakup sebesar 100\% dari total jumlah populasi, dan 1 orang pengurus panti. Pemaparan materi personal hygiene dan sanitasi lingkungan dan protokol kesehatan COVID-19 dapat diterima dan dipahami oleh para penghuni panti, dibuktikan dengan demonstrasi dari peserta penyuluhan saat dilakukan tanya jawab dan atau quiz berdasarkan hasil pengamatan.

Saat sebelum melakukan penyuluhan, anak panti yang sudah menggunakan masker hanya 5 orang serta pengurus panti 1 orang. Setelah dilakukan penyuluhan, di demonstrasikan bagaimana 
memakai masker dengan benar dan diberikan masker, semua anak panti dan pengurus panti sudah menggunakan masker dengan baik. Maka, output dari edukasi mengenai penggunaaan masker yang baik sudah mencapai $100 \%$.

Sebelum dilakukan edukasi mengenai prosedur cuci tangan yang benar, dari hasil pengamatan hari pertama didapatkan hanya 3 orang dari 17 anak panti yang mencuci tangan setelah melakukan suatu kegiatan sebelum makan. Setelah dilakukan edukasi dan demonstrasi cara mencuci tangan 6 langkah saat penyuluhan, dan pemberian sabun cuci tangan, pada hari kedua ditemukan bahwa ada 17 anak panti yang mencuci tangan 6 langkah setelah melakukan kegiatan dan sebelum makan siang. Dapat dinilai bahwa output dari edukasi prosedur mencuci tangan sebesar 100\% dengan catatan 3 anak yang belum sekolah dibantu pada saat pelaksanaannya.

Edukasi mengenai protokol kesehatan COVID-19 di lingkungan panti membuahkan hasil output sebesar 70,58\%. Hal ini dapat dinilai dari sebelum melakukan pemaparan materi protokol kesehatan COVID-19, anak panti banyak yang belum mengerti saat diberikan pertanyaan. Setelah dilakukannya edukasi, anak panti yang bisa menjawab pertanyaan saat quiz dengan baik dan lengkap sebanyak 12 orang dari total 17 orang. Output sebesar $70.58 \%$ dari jumlah total populasi bisa dikategorikan berhasil karena sebanyak 17,64\% dari total populasi pendidikannya 1 TK dan 2 belum sekolah.

\section{Kuesioner untuk menilai penguatan perilaku sebagai output intervensi}

Kuesioner untuk menilai perubahan perilaku sebagai output dari intervensi yang telah dilakukan dibuat dalam 3 kategori yaitu meliputi; 1. Personal Hygine dan 2. Protokol kesehatan yang masing masing memiliki 6 pertanyaan dengan pilihan alternatif jawaban yaitu; selalu, jarang dan tidak pernah. Kuesioner ini diikuti oleh total populasi yaitu sebanyak 17 anak panti.

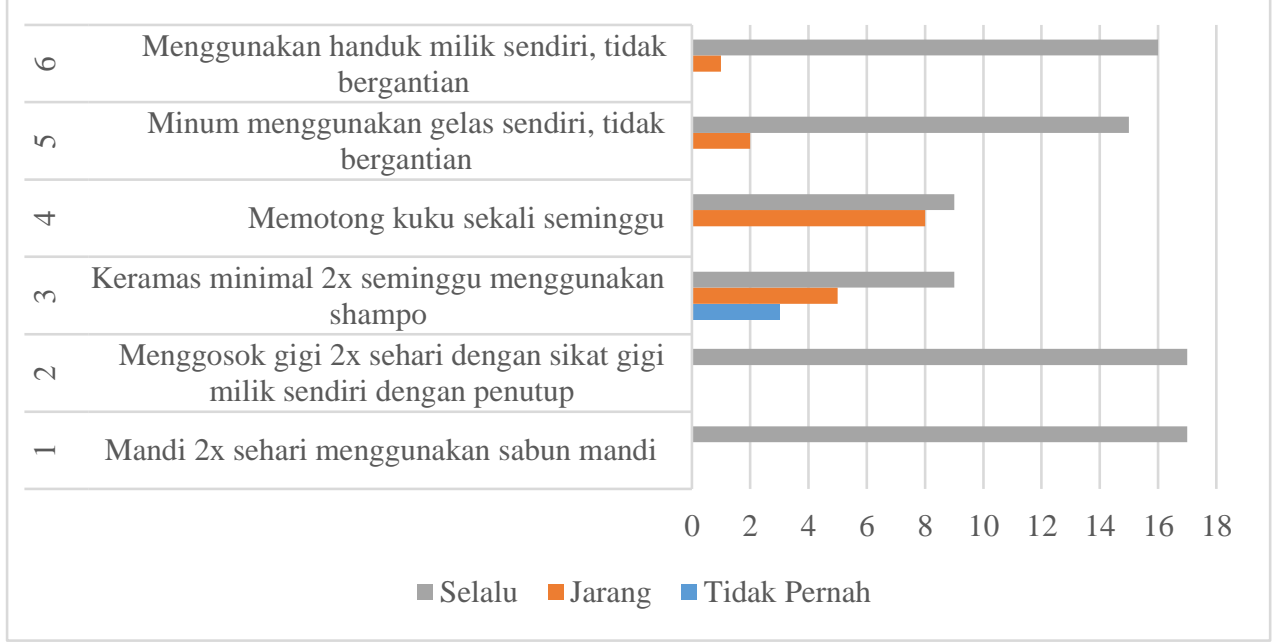

Grafik 1. Penilaian Perubahan Perilaku Personal Hygiene 
Berdasarkan grafik 1, diketahui bahwa penghuni panti telah menerapkan personal hygiene sesuai dengan materi edukasi berupa penyuluhan mengenai personal hygiene yang diinisiasi oleh peneliti, namun masih terdapat beberapa perilaku yang kurang memuaskan berupa jarang memotong kuku seminggu sekali sebanyak 8 orang anak (47,05\%), tidak pernah keramas menggunakan shampoo sebanyak 3 orang anak $(17,64 \%)$ dan jarang keramas menggunakan shampoo sebanyak 5 orang anak $(29,4 \%)$ dan sebanyak 2 orang anak $(11,76 \%)$ masih belum terbiasa minum menggunakan gelas milik sendiri dari seluruh total populasi.

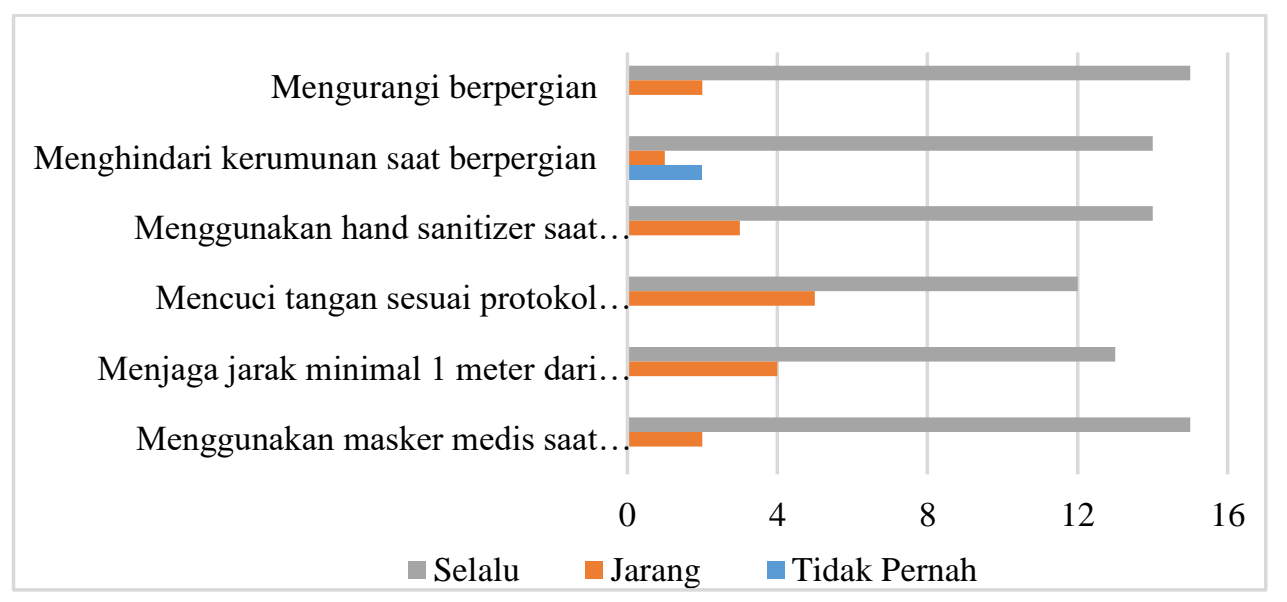

\section{Grafik 2. Penilaian Perubahan Perilaku Sesuai Protokol Kesehatan Covid-19}

Pada grafik 2, dapat dilihat bahwa penghuni panti telah mulai menerapkan protokol kesehatan COVID-19 sesuai dengan materi edukasi berupa penyuluhan, demontrasi dan praktek (simulasi experience) yang diinisiasi oleh peneliti. Mengingat pentingnya menerapkan protokol kesehatan COVID-19 untuk mencegah penularan pada kelompok rentan seperti panti asuhan, berdasarkan grafik 2 dari keseluruhan total populasi masih terdapat beberapa perilaku yang kurang memuaskan seperti terdapat sebanyak 2 orang anak (11,76\%) yang jarang menggunakan masker saat berpergian, sebanyak 4 orang anak $(23,52 \%)$ yang jarang menjaga jarak minimal 1 meter dengan orang sekitar. Untuk prosedur mencuci tangan 6 langkah sesuai prokes dan menggunakan hand sanitizer saat berpergian masih terdapat 5 orang anak $(29,41 \%)$ dan 3 orang anak $(17,64 \%)$ yang jarang melakukannya. Sebanyak 2 orang anak $(11,76 \%)$ yang tidak pernah menghindari kerumunan saat berpergian dan sebanyak 1 orang anak $(5,8 \%)$ jarang melakukannya, serta sebanyak 2 orang anak $(11,76 \%)$ jarang mengurangi berpergian di masa pandemi ini. 


\section{Diskusi}

\section{Perubahan Perilaku Personal Hygiene}

Setelah dilakukan intervensi terdapat beberapa perubahan penguatan perilaku personal hygiene yang penting berkaitan pandemi ini antara lain selalu memakai sikat gigi milik sendiri yang menggunakan penutup sebesar 100\% dan selalu mandi 2 kali sehari memakai sabun mandi sebesar $100 \%$. Namun masih ditemukan adanya 3 permasalahan yaitu; 1. Masalah yang riskan dan berpotensi dalam penularan COVID-19 adalah terdapat sebanyak 2 orang anak (11,76\%) masih jarang / belum terbiasa selalu minum menggunakan gelas milik sendiri; 2. Perilaku jarang memakai handuk milik sendiri sebesar 5,88\% pada 1 orang anak yang belum sekolah dan 3 . Perilaku jarang memotong kuku seminggu sekali sebesar 47,05\% dimana hal ini perlu mendapat perhatian khusus karena kuku yang panjang berpotensi bila terpapar virus maka dapat menyimpan virus COVID-19 bila tidak mencuci tangan 6 langkah dengan benar selain itu menurut Hamzah terdapat hubungan antara rajin mencuci tangan dengan dan memotong kuku dengan tingginya angka kejadian diare pada anak yang merupakan kasus berpotensi terhadap terjadinya wabah Kejadian Luar Biasa (KLB) yang disertai dengan tingkat kematian yang tinggi di Indonesia. ${ }^{(11)}$

Kurangnya pemahaman materi personal hygiene khususnya mengenai risiko penularan virus COVID-19 melalui droplet yang dapat menempel pada tangan dan kuku yang panjang dan tidak dicuci dengan benar memakai sabun, dan risiko penularan penyakit apapun terutama virus COVID-19 yang dapat terjadi karena pemakaian gelas atau alat makan secara bergantian karena adanya bekas air liur (droplet) pengguna alat tersebut sebelumnya yang menempel pada gelas dapat langsung menulari pengguna alat berikutnya secara langsung melalui mulut dan atau mukosa yang terbuka sebagai port the entre virus COVID-19. ${ }^{(12)}$

\section{Perubahan Perilaku Sesuai Protokol Kesehatan Covid-19}

Hasil identifikasi masalah pada perubahan perilaku sesuai protokol kesehatan COVID-19 yang penting di masa pandemi ini terdapat penguatan perubahan perilaku yang memuaskan setelah dilakukan intervensi, namun masih terdapat sebagian kecil anak yang berperilaku kurang memuaskan seperti terdapat sebesar $11,76 \%$ yang jarang menggunakan masker saat berpergian, sebesar 23,52\% yang jarang menjaga jarak minimal 1meter dengan orang sekitar. Untuk prosedur mencuci tangan 6 langkah sesuai prokes yang masih jarang melakukan sebesar 29,41\% dan jarang menggunakan hand sanitizer saat berpergian sebesar 17,64\%. Sebesar 11,76\% yang tidak menghindari kerumunan saat berpergian dan sebesar 5,8\% jarang melakukannya, serta sebesar 
$11,76 \%$ jarang mengurangi berpergian di masa pandemi ini. Berdasarkan prosentasi sebenarnya intervensi yang dilakukan sudah dikatakan berhasil atau memuaskan karena rata rata sudah diatas 75\% yang selalu menerapkan protokol kesehatan COVID-19, namun karena penularan dan penyebaran virus COVID-19 ini sangat cepat dan mudah terutama untuk populasi yang hidup berkelompok yang rentan terhadap penularan penyakit, dari 1 orang saja sudah dapat menulari yang lainnya maka khusus untuk perubahan perilaku tersebut diharapkan bisa mencapai angka $100 \% .^{(13)}$

\section{Evaluasi Perubahan Perilaku Personal Hygiene dan Perilaku Sesuai Protokol Kesehatan Covid-19}

Evaluasi terhadap kurangnya pemahaman tersebut mungkin disebabkan karena waktu pemaparan edukasi yang kurang, daya tangkap yang berbeda beda karena perbedaan usia dan pendidikan tetapi diberikan materi yang sama, pengulangan/repetition yang sebaiknya dilakukan dan kurangnya keterlibatan pendamping untuk membimbing terutama pada anak panti yang masih kecil.

Untuk penguatan perubahan perilaku personal hygiene dan protokol kesehatan COVID-19 kedepannya, dapat dilakukan edukasi personal hygiene yang diprioritaskan terhadap; 1. Pencegahan berbagai penyakit atau terpapar oleh virus COVID-19 dan risiko atau bahayanya dan mudahnya cara penularan virus sehingga tindakkan mengikuti protokol kesehatan COVID-19 sangat penting; 2. Pemilahan ruang pada saat pemaparan materi sesuai usia dan atau jenjang pendidikannya; 3. Pemberian materi yang lebih menyesuaikan usia dan atau pendidikannya; 4. Perlunya dilakukan kunjungan berikutnya untuk evaluasi dan sebagai repetisi dan 5. Melakukan pembinaan kepada pembina dan atau pengurus panti supaya mereka mengerti dan dapat menjadi role model serta menjadi pembina untuk membimbing anak anak yang masih kecil.

\section{Kesimpulan}

Hasil penelitian ini menunjukkan bahwa edukasi, demonstrasi, dan praktek yang dilakukan dapat memberikan potensi perubahan perilaku menjadi lebih baik. Walaupun penelitian ini bersifat sebagai penelitian pendahuluan (preliminary study), tetapi data yang diperoleh dapat menjadi masukkan dan pemetaan/mapping bahwa intervensi untuk perubahan perilaku di panti asuhan bisa ditingkatkan ke level penelitan yang lebih besar. 


\section{Persetujuan Etik}

Penelitian ini tidak menggunakan persetujuan etik karena merupakan penelitian pendahuluan dan telah mendapatkan persetujuan dari pimpinan Panti Asuhan Betlehem dan responden yang terlibat dalam penelitian.

\section{Ucapan Terima Kasih}

1. Universitas Katolik Soegijapranata yang telah memberikan dana pengabdian yang terintegrasi dengan field lab sehingga artikel ini dapat diterbitkan.

2. Bapak Letnan Supriono Da Lopez, selaku Pimpinan Panti Asuhan Betlehem dan anak anak panti yang telah bersedia menerima tim peneliti untuk melakukan wawancara, observasi dan memberikan waktu dan tempat kepada tim peneliti untuk melaksanakan penyuluhan, demonstrasi, simulasi dan penempelan poster kesehatan.

3. Bapak Perigrinus Hermin Sebong, MPH selaku koordinator pengabdian dan penelitian Fakultas Kedokteran Universitas Katolik Soegijapranata yang telah menginisiasi serta mengintegrasikan program field lab dengan pengabdian dan penelitian.

\section{Daftar Pustaka}

1. Ginting H. Perubahan perilaku sebagai respon terhadap wabah COVID-19 [Internet]. Himpsi.or.Id. 2020 [cited 2021 Aug 20]. Available from: https://himpsi.or.id/blog/materiedukasi-covid-19-5/post/perubahan-perilaku-sebagai-respon-terhadap-wabah-covid-19127\#blog_post_comment_quote

2. Kementrian Kesehatan Republik Indonesia. 5 M dimasa Pandemi COVID-19 di Indonesia [Internet]. Kementrian Kesehatan Republik Indonesia. 2021 [cited 2021 Aug 21]. Available from: http://www.padk.kemkes.go.id/article/read/2021/02/01/46/5-m-dimasa-pandemicovid-19-di-indonesia.html

3. BNPB. Cara Memakai Masker yang Benar [Internet]. covid19.go.id. 2020. Available from: https://covid19.go.id/edukasi/masyarakat-umum/cara-memakai-masker-yang-benar2

4. WHO. Transmisi SARS-CoV-2: implikasi terhadap kewaspadaan pencegahan infeksi. 2020;1-10.

5. Pemerintah. Pembatasan sosial berskala besar dalam rangka percepatan penanganan corona virus disease 2019 (COVID-19) [Internet]. 2020. Available from: https://peraturan.bpk.go.id/Home/Details/135059/pp-no-21-tahun-2020

6. Permatasari D. Kebijakan Covid-19 dari PSBB hingga PPKM Empat Level. Kompaspedia [Internet]. 2021 Jul 31; Available https://kompaspedia.kompas.id/baca/infografik/kronologi/kebijakan-covid-19-dari-psbb- 
hingga-ppkm-empat-level

7. Andarmoyo S. Personal Hygiene, Konsep, Proses, dan Aplikasi dalam Praktik Keperawatan [Internet]. Yogyakarta: Repository Universitas Muhamadyah Ponorogo; 2016. Available from: http://eprints.umpo.ac.id/2039/

8. Black J. Field trials of health interventions: a toolbox. Aust N Z J Public Health. 2017;41(4):452-452.

9. Kemenkes. Flyer: Etika Batuk [Internet]. Direktorat promosi kesehatan dan pemberdayaan masyarakat kementerian kesehatan ri. 2020. Available from: https://promkes.kemkes.go.id/flyer-etika-batuk

10. Terhadap A, Pengalaman K, Dale E. Mudir: Jurnal Manajemen Pendidikan Vol. I No. 1, Januari 2019 ISSN: 2655-9331. 2019; I (1):58-78.

11. Hamzah B. Analisis hubungan personal hygiene dengan kejadian diare pada anak usia 4-5 tahun di desa muntoi timur kabupaten bolang mongondow. J Info Kesehat [Internet]. 2020; Vol 10 No. Available from: https://jurnal.ikbis.ac.id/infokes/issue/view/7

12. Diah Handayani, Dwi Rendra Hadi, Fathiyah Isbaniah, Erlina Burhan HA. Penyakit Virus Corona 2019. Respirologi Indones [Internet]. 2020; VOL. 40, N. Available from: file:///C:/Users/User/Downloads/101-369-5-PB.pdf

13. Sebong PH, Tjitradinata C, Goldman RE. Promoting COVID-19 prevention strategies in student dormitory setting: A qualitative study. J Am Coll Heal [Internet]. 2021;0(0):1-10. Available from: https://doi.org/10.1080/07448481.2021.1926271 